\title{
SELECTION CRITERION FOR IMPROVED GRAIN YIELDS IN ETHIOPIAN DURUM WHEAT GENOTYPES
}

\author{
AREGA GASHAW, HUSSEIN MOHAMMED ${ }^{1}$ and HARJIT SINGH ${ }^{2}$ \\ Sirinka Agricultural Research Center, Woldia, Ethiopia \\ ${ }^{1}$ Debub University, College of Agriculture, Awassa, Ethiopia \\ ${ }^{2}$ Alemaya University, College of Agriculture, Harar, Ethiopia
}

(Received 4 December, 2006; accepted 26 February, 2007)

\begin{abstract}
Wheat (Triticum durum Desf.) is the most important cereal crop grown in the intermediate and highland areas of northeastern Ethiopia. Durum wheat dominates in these areas where water logging is the major production constraint. Because of the predominant problem of water logging coupled with other various biotic and abiotic production hobbling factors, the average productivity of wheat in the northeastern region never exceeds 8.4 $\mathrm{ha}^{-1}$, which is below the national average of $14.4 \mathrm{ha}^{-1}$ (ECSA, 2002). Screening of wide durum wheat germplasm has been undertaken to improve durum wheat grain yield. But, selection based on the performance of grain yield alone, a polygenically controlled complex character, is usually not very efficient. An experiment was conducted at Geregera testing site of Sirinka Agricultural Research Centre, during the 2003-cropping season with the objective of estimating the associations between yield and yield-related traits and to identify direct and indirect effects of characters for durum wheat grain yield improvement. The experimental material consisted of 44 indigenous durum wheat genotypes, which are randomly taken from the indigenous germplasm collections. Mean sum of squares for all the characters considered showed highly significant differences $(\mathrm{P}<0.01)$ indicating the presence of adequate variability. Grain yield had strong positive correlations $(\mathrm{P}<0.01)$ with plant height, number of kernels spike ${ }^{-1}$, grain yield plant ${ }^{-1}$, biological yield and thousand-kernel weight. On the contrary, grain yield had strong negative correlation $(\mathrm{p}<0.01)$ with days to heading suggesting that the usefulness of selecting early heading genotypes with long grain filling period in improving grain yield. The results of genotypic correlation indicate that maximum positive direct effect on grain yield was exerted by biological yield (1.08) followed by days to maturity (0.91) and harvest index (0.69). While, maximum negative direct effects were exerted by days to heading $(-0.72)$ and grain filling period (-0.52). Therefore, days to heading, biological yield and harvest index could be used as an indirect selection criterion for better grain yield. Thus, selecting early heading genotypes having high biological yield and harvest index could improve grain yield.
\end{abstract}

Key Words: Ethiopia, harvest index, Triticum durum, variability

\section{RÉSUMÉ}

Le blé (Triticum durum Desf) est l'une des cultures céréalières les plus importantes plantées dans les régions montagneuses et intermédiaires du Nord- Est de l'Ethiopie et où le blé durum domine, quelque part dans les surfaces couvertes d'eau qui constituent la contrainte majeure à la production. A cause des facteurs de production biotiques et abiotiques emboîtant le lieu, la moyenne de la productivité du blé n’a jamais dépassé 8.4 qt ha- ${ }^{1}$ se trouvant en dessous de la moyenne nationale de 14.4 qt ha- ${ }^{-1}$ (ECSA, 2002). Le dépistage d'un large germoplaste du blé durum avait été pratiqué pour améliorer la culture du blé durum. Mais, une sélection basée sur la performance de la production de la graine seule, un caractère complexe polygénicalement contrôlé n'est généralement très efficace. Une expérience était montée à la site de Geregera du Centre de Recherche Agronomique de Sirinka durant la saison de la récolte de 2003 ayant pour objectif l'estimation des associations entre la production et les traits de production y relatifs et l'identification directe et indirecte des effets des caractères pour 
l'amélioration de la production du grain de blé durum. Le matériel expérimental comprenait 44 génotypes du blé durum indigène pris au hasard à partir des collections de germoplasmes indigènes. La somme moyenne des carrés pour tous les caractères considérés avait montré des différences significatives élevées $(\mathrm{P}<0.01)$, la présence d'une variabilité adéquate. La production de la graine avait des fortes corrélations positives $(\mathrm{p}<0.01)$ en hauteur et en nombre de noyaux spike $-{ }^{1}$, la plante- ${ }^{1}$ de la production de la graine, la production biologique, et des milliers de hauteur des noyaux. Au contraire, la production de la graine avait une forte corrélation négative $(<0.01)$ avec les jours d'avance suggérant l'utilité de sélectionner en avance des génotypes précoces des graines substantielles pour une grande période à l'amélioration de la production de la graine. Les résultats de la corrélation génotypique indiquent que l'effet du maximum positif direct sur la production de la graine était exercée par une production biologique (1.08) suivie des jours à la maturité (0.91) et l'indexe de la récolte (0.69). Un moment, les effets directs du maximum négatif étaient exercés par les jours précédents (-0.72) et la période substantielle (-0.52). Donc, les jours d'avance, la production biologique et l'indexe de récolte pouvaient être utilisés comme un critère de sélection indirecte pour la meilleure production de la graine. Sélectionner en avance les génotypes précoces ayant une production biologique élevée et un indexe de récolte pouvait améliorer la production de la graine.

Mots Clés: Ethiopie, indexe de la récolte, Triticum durum, variability

\section{INTRODUCTION}

Wheat is the most important cereal crops grown in the intermediate and highland areas of northeastern Ethiopia, and is a dominant crop in areas where water logging is the major production constraint. Because of various biotic and abiotic production hobbling factors, the average productivity of wheat never exceeds $8.4 \mathrm{qt} \mathrm{ha}^{-1}$, which is below the national average of $14.4 \mathrm{qt}$ ha ${ }^{-1}$ (ECSA, 2002). Screening of wide durum wheat germplasm has been done to improve durum wheat grain yield. But, selection based on the performance of grain yield alone, a polygenically controlled complex character, is usually not very efficient (Singh and Singh, 1973; Sastri, 1974). Thus, identifying and manipulating characters contributing to grain yield is important as it increases breeding efficiency.

In light of this therefore, easily measurable characters with high heritability and having useful relationship with grain yield are of paramount importance to practice indirect selection for high yield (Falconer and Mackey, 1996). Correlation studies are, therefore, useful in disclosing the magnitude and direction of these relationships between the different characters and grain yield. Correlation between various physiological and morphological traits results from complex interrelationships between grain yield and the traits and among the traits themselves. But it does not give an exact picture of the relative importance of direct and indirect effects of the various yield attributes (Bhatt, 1973). Thus, in order to get a clear picture of the inter-relationship between grain yield and other characters, direct and indirect effects should be worked out using path coefficient analysis at genotypic level (Saxena et al., 1979; Dokuyucu and Akkaya, 1999). The advantage of path coefficient analysis is that, it permits the partitioning of the correlation coefficient into its components; one component being the path coefficient or standardized partial regression coefficient that measures the direct effect of a predictor variable upon its response variable; the second component being the indirect effect(s) of a predictor variable (Dewey and Lu, 1959; Sharma and Ahmed, 1978; Kumar and Chauhan, 1979).

Getachew et al. (1993) reported the effectiveness of indirect selection for grain yield through plant height and thousand kernel weight, in addition to direct selection for grain yield. In another study, Getachew (1997) reported maximum direct effect of number of tillers per plant and thousand kernel weight on grain yield per plant. Another study by Srivastava et al. (1980) indicated that direct effect of grain yield per plant on grain yield was positive and high, whereas number of kernels per spike and thousand kernel weight had negative and low direct effect.

Thus, to make effective selection for high grain yield a thorough understanding of yield contributing characters and their interrelationships among themselves and with yield is necessary. Information on the extent and nature 
of interrelationship among characters in durum wheat is scanty for moisture-stressed areas of northeastern Ethiopia. The present study was, therefore, conducted with the objectives of estimating the genotypic and phenotypic associations among characters and to determine the direct and indirect effects of yield related traits on grain yield

\section{MATERIALSAND METHODS}

A field experiment was conducted at Geregera testing site of Sirinka Agricultural Research Center (SARC) in northeastern Ethiopia during the 2003 cropping season. Geregera is located at an altitude of 2650 meter above sea level with annual rainfall of $1105 \mathrm{~mm}$. The soil type is generally characterized as clay (70.6\%); containing $1.0 \%$ organic carbon, $0.2 \% \mathrm{~N}_{2}$ and $9.2 \% \mathrm{P}_{2} \mathrm{O}_{5}$ with $\mathrm{pH}$ of 5.6. Rainfall is erratic in distribution, often unpredictable and is uni-modal, which starts in the first week of July and stops at the end of August.

The experimental material consisted of fortyfour genotypes, which were randomly taken from the indigenous germplasm collections. The materials were collected from the central highlands and northwestern part of the country, where durum wheat is cultivated widely. Each genotype was planted in a plot size of $2 \mathrm{~m}^{2}$ (4 rows, each $2.5 \mathrm{~m}$ long, with $20 \mathrm{~cm}$ spacing between rows).

Data on different agronomic traits were collected both on plant and plot basis. Analysis of variance, using completely randomised block design, was computed for all the characters evaluated as per Gomez and Gomez (1984). Phenotypic and genotypic correlation coefficients were estimated using the standard procedure suggested by Miller et al. (1958) from the corresponding variance and covariance components as:

Phenotypic correlation coefficient

$$
\left(r_{p_{x y}}\right)=\frac{\sigma p_{X Y}}{\left[\sqrt{\sigma_{p_{X}}^{2} * \sigma_{p_{Y}}^{2}}\right]}
$$

Genotypic correlation coefficient

$$
\left(r_{g_{x y}}\right)=\frac{\sigma_{g_{x Y}}}{\left[\sqrt{\sigma^{2} g_{x}^{*} \sigma^{2} g_{y}}\right]}
$$

Where, $\boldsymbol{r} p_{x y}=$ phenotypic correlation coefficient between character $\mathrm{X}$ and $\mathrm{Y}$ and

$\boldsymbol{r} g_{x y}=$ Genotypic correlation coefficients between character $\mathrm{X}$ and $\mathrm{Y}$

Path coefficient analysis was computed as suggested by Wright (1921) and worked out by Dewey and Lu (1959) using phenotypic as well as genotypic correlation coefficients as per the following relationship:

$$
\boldsymbol{r}_{i j}=\boldsymbol{p}_{i j}+\boldsymbol{\Sigma}_{i k} \boldsymbol{p}_{k j}
$$

Where, $r_{i j}$ is the mutual association between the dependent character, i (yield-related trait) and independent character, $\mathrm{j}$ (grain yield) as measured by the correlation coefficients; $\mathrm{P}_{\mathrm{ij}}$ is the components of direct effects of the independent character (i) on the dependent character (j) as measured by the path coefficients; and

$$
\boldsymbol{\Sigma}_{i k} \boldsymbol{p}_{k j}
$$

is the summation of components of indirect effects of a given independent character (i) on a given dependent character (j) via all other independent characters $(\mathrm{k})$. Whereas the contribution of the remaining unknown characters is measured as the residual which is calculated as:

$$
\boldsymbol{p}_{R}=\sqrt{\left(1-\boldsymbol{\Sigma} \boldsymbol{p}_{i j} \boldsymbol{r}_{i j}\right)}
$$

\section{RESULTS AND DISCUSSION}

All the characters considered showed significant differences $(\mathrm{P}<0.05)$ among the evaluated genotypes indicating the presence of adequate variability (Table 1). This is in agreement with the findings of Getachew et al. (1993), indicating that Ethiopian durum wheat germplasm exhibits tremendous genetic variability. Such immense 
TABLE 1. Mean squares for some quantitative characters in indigenous durum wheat germplasm

\begin{tabular}{lllllllllllll}
\hline $\begin{array}{l}\text { Source of } \\
\text { variation }\end{array}$ & df & \multicolumn{10}{c}{ Characters } \\
\cline { 2 - 11 } & & DH & DM & GFP & PH & NSS & NK & GYP & BY & TKW & HI & GY \\
\hline Replications & 2 & 7.0 & 158.2 & 99.5 & 104.8 & 1.0 & 3.0 & 0.01 & 117.6 & 3.3 & 29.5 & 417.5 \\
Genotypes & 43 & $55.6^{* *}$ & $89.4^{* *}$ & $55.4^{*}$ & $230.8^{* *}$ & $3.1^{* *}$ & $22.9^{* *}$ & $0.09^{* *}$ & $394.0^{* *}$ & $42.1^{* *}$ & $15.2^{*}$ & $525.5^{* *}$ \\
Error & 86 & 13.2 & 25.3 & 32.7 & 29.8 & 0.8 & 7.7 & 0.03 & 183.2 & 8.3 & 5.5 & 278.1 \\
Mean & & & & & & & & & & & & \\
CV\% & 75.1 & 132.4 & 57.3 & 90.4 & 15.8 & 27.9 & 1.09 & 8.8 & 38.9 & 36.6 & 3197 \\
\hline
\end{tabular}

Where, $\mathrm{df}=$ degree of freedom, $\mathrm{DH}=$ Days to heading, $\mathrm{DM}=$ Days to maturity, GFP=Grain filling period, $\mathrm{PH}=\mathrm{Plant}$ height, NSS=Number of spikelets per spike, NK= Number of kernels per spike, GYP=Grain yield per plant, BY= Biological yield, $\mathrm{TKW}=$ Thousand kernel weight, $\mathrm{HI}=$ harvest index and $\mathrm{GY}=\mathrm{Grain}$ yield, * ** indicates significant at $5 \%$ and $1 \%$ probability levels, respectively.

TABLE 2. Genotypic (below diagonal) and phenotypic (above diagonal ) correlations of indigenous durum wheat genotypes

\begin{tabular}{|c|c|c|c|c|c|c|c|c|c|c|}
\hline Characters & $\mathrm{DH}$ & DM & GFP & $\mathrm{PH}$ & NSS & NK & BY & TKW & $\mathrm{HI}$ & GY \\
\hline $\mathrm{DH}$ & & $0.472^{\star \star}$ & $-0.316^{\star}$ & -0.284 & $0.371^{*}$ & 0.074 & -0.093 & -0.170 & -0.287 & -0.225 \\
\hline $\mathrm{DH}$ & $0.804^{\star *}$ & & $0.688^{\star \star}$ & -0.006 & $0.422^{\star *}$ & 0.187 & 0.021 & 0.100 & -0.208 & -0.078 \\
\hline GFP & -0.015 & $0.583^{*}$ & & 0.227 & 0.149 & 0.141 & 0.100 & 0.248 & 0.012 & 0.102 \\
\hline $\mathrm{PH}$ & $-0.536^{*}$ & 0.050 & $0.817^{\star \star}$ & & 0.227 & $0.378^{\star}$ & $0.598^{* *}$ & $0.371^{*}$ & -0.078 & $0.529^{* *}$ \\
\hline NSS & 0.498 & $0.741^{\star *}$ & $0.565^{\star}$ & 0.249 & & $0.633^{* *}$ & 0.234 & 0.121 & -0.202 & 0.120 \\
\hline NK & -0.024 & 0.301 & $0.540^{\star}$ & $0.520^{*}$ & 0.501 & & $0.301^{*}$ & 0.232 & 0.073 & $0.318^{\star}$ \\
\hline$B Y$ & -0.429 & 0.131 & $0.806^{\star \star}$ & $0.847^{\star \star}$ & 0.419 & $0.728^{* *}$ & & $0.314^{*}$ & -0.166 & $0.879^{* *}$ \\
\hline TKW & -0.373 & 0.254 & $0.936^{\star *}$ & $0.553^{*}$ & 0.051 & 0.401 & $0.594^{*}$ & & 0.203 & $0.405^{\star *}$ \\
\hline $\mathrm{HI}$ & -0.467 & $-0.514^{*}$ & -0.227 & -0.058 & -0.472 & 0.063 & -0.365 & 0.280 & & $0.315^{*}$ \\
\hline GY & $-0.751^{\star *}$ & -0.212 & $0.670^{*}$ & $0.843^{\star *}$ & 0.113 & $0.781^{* *}$ & $0.802^{\star *}$ & $0.818^{* *}$ & 0.264 & \\
\hline
\end{tabular}

Where, $\mathrm{df}=$ degree of freedom, $\mathrm{DH}=$ Days to heading, $\mathrm{DM}=$ Days to maturity, GFP=Grain filling period, $\mathrm{PH}=\mathrm{Plant}$ height, NSS=Number of spikelets per spike, NK= Number of kernels per spike, GYP=Grain yield per plant, BY= Biological yield, $\mathrm{TKW}=$ Thousand kernel weight, $\mathrm{HI}=$ harvest index and $\mathrm{GY}=$ Grain yield, * ** indicates significant at $5 \%$ and $1 \%$ probability levels, respectively.

genetic variation is a great resource for the country and the world at large.

Phenotypic and genotypic correlation coefficients of grain yield with other characters are presented in Table 2. Genotypic correlation coefficient values were greater for most of the characters than their corresponding phenotypic correlation coefficient values, indicating inherent association of the characters. At phenotypic level, grain yield had significant positive associations with plant height $\left(\mathrm{r}_{\mathrm{p}}=0.529\right)$, biological yield $\left(r_{p}=0.879\right), 1000$ - kernel weight $\left(r_{p}=0.405\right)$, number of kernels per spike $\left(r_{p}=0.318\right)$ and harvest index
(0.315). Similarly, at genotypic level, grain yield had very strong positive correlation $(\mathrm{P}<0.01)$ with plant height $\left(r_{\mathrm{o}}=0.843\right)$, number of kernels per spike $\left(r_{\mathrm{g}}=0.781\right)$, biological yield $\left(\mathrm{r}_{\mathrm{g}}=0.802\right)$ and 1000- kernel weight $\left(r_{g}=0.818\right)$, implying that improving one or more of the above characters could result in high grain yield. On the contrary, grain yield had strong negative correlation $(\mathrm{P}<$ $0.01)$ with days to heading $\left(\mathrm{r}_{\mathrm{g}}=-0.751\right)$, suggesting that selecting early heading genotypes with long grain filling period would give high grain yield under moisture stress area. Similar results were found by Amin et al. (1992), Van Oosteron and 
Acevedo (1992) who reported that early heading genotypes with adequate grain filling period escape terminal moisture stress and, thus give better grain yield.

Path analysis of grain yield with other characters. The phenotypic relationship present between the dependent and independent characters was fully explained (99\%) by the phenotypic path coefficient analysis model (Table 3). High and positive phenotypic direct effects on grain yield were exhibited by days to maturity (7.06), followed by biological yield (0.96) and harvest index (0.47). The phenotypic correlation coefficient between grain yield and biological yield and harvest index were almost equal to their corresponding phenotypic direct effect, indicating that phenotypic correlation coefficient explained true relationship between them. Whereas the maximum positive phenotypic direct effect of days to maturity on grain yield was counter balanced by the phenotypic indirect effects via days to heading and grain filling period and rendering weak negative phenotypic correlation with grain yield.

Though plant height, number of kernels per spike, grain yield per plant and thousand kernel weight had significant positive phenotypic correlation with grain yield, their direct effects were low indicating that these effects are sources of the phenotypic correlation. The significant and positive phenotypic correlation between plant height and grain yield was due to the positive indirect effects via days to heading and biological yield. Similarly, the positive indirect effects of number of kernels per spike via days to maturity and biological yield caused positive and significant phenotypic correlation with grain yield. The direct effects of grain filling period, days to heading and days to maturity on grain yield were counter balanced by one another making their phenotypic correlation coefficients insignificant.

Similar to phenotypic path coefficient analysis model, genotypic path coefficient analysis had entirely explained (99\%) the relationship between the dependent and independent characters (Table 4 and Fig. 1). Maximum positive direct effect on grain yield was exerted by biological yield (1.07) followed by days to maturity (0.91) and harvest index (0.69). Days to maturity had weak negative genotypic correlation with grain yield though it had positive direct effect. The cause of negative genotypic correlation for days to maturity with grain yield is the negative indirect effects via days to heading and grain filling period. On the other hand, biological yield and harvest index had strong positive direct effect with grain yield.

Maximum negative direct effect was exerted by days to heading $(-0.72)$ and grain filling period $(-0.52)$. Days to heading, in addition to the maximum negative direct effect on grain yield, it had significant negative genotypic correlation with grain yield. Grain filling period, number of kernels per spike and thousand kernel weight had positive genotypic correlation with grain yield though their corresponding direct effects were negative. The maximum negative direct effect of grain filling period was counter balanced by its positive indirect effects via days to maturity and biological yield and rendered the genotypic correlation coefficient positive and significant.

TABLE 3. Estimates of phenotypic direct (bolded diagonal) and indirect (off-diagonal) effects of different characters on grain yield of indigenous durum wheat genotypes

\begin{tabular}{lllllll}
\hline Characters & DH & DM & GFP & BY & TKW & HI \\
\hline DH & -5.40 & 3.33 & 2.07 & -0.09 & -0.002 & -0.14 \\
DM & -2.55 & 7.06 & -4.51 & 0.02 & 0.001 & -0.10 \\
GFP & 1.70 & 4.85 & -6.55 & 0.10 & 0.003 & 0.01 \\
BY & 0.50 & 0.15 & -0.65 & 0.96 & 0.003 & -0.08 \\
TKW & 0.92 & 0.71 & -1.63 & 0.30 & 0.011 & 0.10 \\
HI & 1.55 & -1.47 & -0.08 & -0.16 & 0.002 & 0.47 \\
\hline
\end{tabular}

Residual $=0.0083$ 
TABLE 4. Estimates of genotypic direct effects (bolded diagonal values) and indirect effect (off-diagonal values) of different characters on kernel yield per plot of indigenous durum wheat genotypes

\begin{tabular}{lllllll}
\hline Characters & DH & DM & GFP & BY & TKW & HI \\
\hline DH & -0.72 & 0.73 & 0.01 & -0.46 & 0.009 & -0.32 \\
DM & -0.58 & 0.91 & -0.30 & 0.14 & -0.006 & -0.35 \\
GFP & 0.01 & 0.53 & -0.52 & 0.87 & -0.022 & -0.16 \\
BY & 0.31 & 0.12 & -0.42 & 1.08 & -0.014 & -0.25 \\
TKW & 0.29 & 0.23 & -0.49 & 0.64 & -0.024 & 0.19 \\
HI & 0.34 & -0.47 & 0.12 & -0.39 & -0.017 & 0.69 \\
\hline
\end{tabular}

Residual $=0.0002$

\section{DM} BY

DH

Figure 1. Genotypic direct effects of some characters on grain yield.

Therefore, days to heading, biological yield and harvest index could be used as an indirect selection criterion for better grain yield.

To improve the target trait, durum wheat grain yield, from this study we can conclude that indirect selection should be designed in such a way that early heading genotypes having high biological yield and harvest index should be considered as a selection criteria.

\section{ACKNOWLEDGMENTS}

The following are thanked for their assistance: Ato Solomon Mitiku, Awol Ahmed, Abraha Alemu, Moges Muluye, Awol Mohammed and the late Ali Demeke. The research was financed by Ethiopian Agricultural Research Organization (EARO), and Agricultural Research and Training Project (ARTP). Dr. Wondimu Bayu is appreciated for valuable input in this paper for his unreserved technical and mechanical comments and suggestions.

\section{REFERENCES}

Amin, M.R., Barma, N.C.D. and Razzague, M.A. 1992. Variability, heritability, genetic advance and correlation study in some quantitative characters in durum wheat. Rachis News Letter 11: 30-32. 
BFED, The Amhara National Regional State, Bureau of Finance and Economic Development (BFED). 2001. Annual Statistical Bulletin. pp. 29-30.

Bhatt, G.M. 1973. Significance of path coefficient analysis in determination of nature of character association. Euphytica 22: 338-343.

Cochran, W.G. and Cox, G.M. 1957. Experimental Designs. John Wiley and Sons, Inc., New York, USA. 611pp.

Dewey, D.R. and Lu, K.H. 1959. A correlation and path coefficient analysis of crested wheat grass seed production. Agronomy Journal 51:515-518.

Dokuyucu, T. and Akkaya, A. 1999. Path coefficient analysis and correlation of grain yield and yield components of wheat (Triticum aestivum L.) genotypes. Rachis News Letter18: 17-20.

Eastern, Central and Southern Africa (CSA), 2002. Central Statistics Authority (CSA). 2002. Statistical Abstract, 96pp.

Falconer, D.S. and Mackay, F.C. 1996. Introduction to Quantitative Genetics (Fourth edition). Long man, New York, USA.

Getachew, B., Tesemma, T. and Mitiku, D. 1993. Variability and correlation studies in durum wheat in Alem-Tena, Ethiopia. Rachis News Letter 12:38-40.

Getachew, B. 1997. Genetic variation, Breeding potential and cytogenetic profile of Ethiopian Tetraploid wheat (Triticum turgdum) landraces. PhD dissertation, Swedish University of Agricultural Sciences. Uppsala, Sweden.

Hadjichristodoulou, A.1989. Environmental correlations among grain yield and other important traits of wheat in dry lands. Euphytica 44: 143-150.

Jaradat, A.A. 1991. Levels of phenotypic variation for developmental traits in landrace genotypes of durum wheat (Triticum durum (Desf) from Jordan. Euphytica 51: 265-271.

Jarrah, M. and Geng, I. 1997. Variability of morphological traits of Mediterranean durum wheat cultivars. Rachis News Letter 16: 5257.
Kumar, S. and Chauhan, B.P.S. 1979. Association analysis in the segregating populations of linseed. Indian Journal of Genetics 39: 506510.

Lebsock, K.L. and Amaya, A. 1969. Variation and co-variation of agronomic traits in durum wheat. Crop Science 9: 372-375.

Miller, P.A., Williams, J.C., Robinson, H.F. and Comstock, R.E. 1958. Estimates of genotypic and Environmental Variances and Covariances in Upland cotton and their implications in selection. Agronomy Journal 50:126-131.

Poehlman, J. M. and Sleper, D.A. 1995. Breeding Field Crops ( $4^{\text {th }}$ Edition). Iowa State University Press. Iowa, USA. pp. 259-261.

Purseglove, J.W. 1975. Tropical Crops; Monocotyledons. John Wiley \& Sons, Inc., New York, USA. pp. 287-291.

Sastri, A.B. 1974. Path analysis of yield components in Tobacco. Indian Journal of Genetics 34:57-58.

Saxena, M.B.L., Rao, G.V.S. and Verma, R.C. 1979. Path analysis in panicum miliaceum. Indian Journal of Genetics 39:237-239.

Sharma, J.C. and Ahmad, Z. 1978. Indirect selection response in spring wheat. Indian Journal of Genetics 38: 292-298.

Sharma, J.R. 1998. Statistical and Biometrical Techniques in Plant Breeding. New Age International Publishers, New Delhi, India. 432pp.

Singh, T.P. and Singh, K.B. 1973. Association of grain yield and its components in segregating populations of green gram. Indian Journal of Genetics 33: 112-117.

Srivastava, S.N.,Sarkar, D.K. and Mallic, M.H. 1980. Association analysis in rain fed wheat. Indian Journal of Genetics 40: 512-514.

Van Oosteron, E.J. and Acevedo, E. 1992. Adaptation of Barley (Hordeum vulgare L.) to harsh Mediterranean environments. Euphytica 62: 29-38.

Wright, S. 1921. Correlations and causations. Journal of Agricultural Research 20:557-587. 